\title{
How populist crisis rhetoric affects voters in Switzerland
}

\author{
Dominique Stefanie Wirz, University of Fribourg, DCM Department of Communication and \\ Media Research, Switzerland* \\ Martin Wettstein, University of Zurich, IKMZ Department of Communication and Media Research, \\ Switzerland \\ Anne Schulz, University of Oxford, Reuters Institute for the Study of Journalism, United Kingdom \\ Nicole Ernst, University of Zurich, IKMZ Department of Communication and Media Research, \\ Switzerland \\ Christian Schemer, Johannes Gutenberg-Universität Mainz, Department of Communication \\ Werner Wirth, University of Zurich, IKMZ Department of Communication and Media Research, \\ Switzerland
}

*Corresponding author: dominique.wirz@unifr.ch

\begin{abstract}
Right-wing populism has a long tradition in Switzerland. Nevertheless, only little is known about how populist messages in the media contribute to the success of the Swiss People's Party (SVP) and to the acceptance of the party's anti-immigration policies. In this study, we combine data from a large media content analysis (including newspapers and TV news shows) with data from a panel-survey in order to address this research gap. Thereby we differentiate between effects driven by the content and the form of right-wing populist communication. While right-wing populist content depicts immigrants and the political elite as a threat to the Swiss people, populist style evokes the sense of a crisis by emotionalizing and dramatizing the message. Populist style is therefore assumed to increase the persuasiveness of populist claims. The results of this study suggest that this is the case only for some voters, while it backfires for others.
\end{abstract}

\section{Keywords}

Populism, crisis, anti-immigrant, linkage analysis, media effects

The term crisis has a high popularity in recent politics, be it with regard to refugees, the media, or democracy. It seems that especially populist actors profit from this state. The proclamation of a crisis helps them to put forward their drastic policies and is considered as a key element of populist politics (Moffitt, 2015). Populist actors like to portray themselves as unpolitical persons, who are urged to take action in light of the desperate situation (Mudde, 2004; Taggart, 2000). They turn politics into a campaign to save the country (Canovan, 1999).

In order to evoke a sense of a crisis, populist actors rely on communication styles such as dramatization, emotionalization, and absolutism (e.g., Betz, 1993; Bos \& Brants, 2014; Bracciale \& Martella, 2017). These style elements are often considered as a key feature of populist communication. Compared to substantial populist statements, which reflect the key ideas of the populist ideology, such style elements are not populist per se (Wirth et al., 2016). Nevertheless, they help populist actors to gain attention and spread their messages (e.g., Mazzoleni, Stewart, \& Horsfield, 2003).

Little is known about the effects of the populist crisis rhetoric in the media on citizens' attitudes. Is a populist message more persuasive when it is emotionalized or dramatized? And are all voters equally susceptible to the populist crisis rhetoric? Previous research suggests that populist style elements may increase the persuasiveness of a populist message for certain voter segments (Bos, van der Brug, \& de Vreese, 2013; Hameleers, Bos, \& de Vreese, 2017b). As experimental studies only show short-term effects in response to a single 
media stimulus, more research is needed to answer these questions. A recent field study (Wirz et al., 2018) did not find any additional effects of populist styles over the effects of populist and anti-immigrant statements on emotions and cognitions toward immigrants. However, this study did not differentiate between different groups of participants, as the experimental studies did. It therefore remains an open question if populist styles can increase the persuasiveness of right-wing populist messages for certain voters.

The present study aims to address this research gap using data from Switzerland. The Swiss People's Party (SVP) is often considered as a textbook example of a right-wing populist party (e.g., Albertazzi, 2008). Under the former leader Christoph Blocher, the party has almost doubled its vote share and became the largest party of the country. Some of the SVP's poster campaigns in referenda gained international attention due to their provocative nature ${ }^{1}$. In the Swiss media, the party has taken a dominant position (Udris, 2012). Nevertheless, there is so far no systematic analysis of the effects of right-wing populist communication in the media on citizens' attitudes.

With the present study, we thus aim to make a twofold contribution. By combining data from a content analysis of the immigration debate in Swiss newspapers and TV news shows with data from a panelsurvey, we analyze the effects of rightwing populist communication (i.e., the combination of right-wing and populist statements as well as populist style) on citizens' attitudes towards immigrants, their support for anti-immigration policies, and their vote probability for the SVP. On the one hand, this improves the understanding of how the populist crisis rhetoric may increase the persuasiveness of right-wing populist messages in a real-world setting, and on the other hand, it investigates the effect of right-wing populist communica-

1 See, for example, this article in the Huffington Post: https://www.huffingtonpost.com/global-risk-insights/switzerland-trump-christoph-blocher-_b_9517190.html (last visited on June 4,2018$)$. tion in the media on Swiss citizens' preferences for the SVP and its policies.

The results of our study show that right-wing populist communication may affect attitudes toward immigrants, the support for anti-immigration policies, as well as the vote probability for the SVP. However, not all effects are evidence of persuasion. While individuals who are supportive of the populist ideology can be convinced by the combination of antiimmigrant statements and populist style, we find a reversed effect for individuals who reject the populist ideology. The findings of this study thus suggest that populist crisis rhetoric in the media may mobilize voters who are inclined towards the populist ideology, and that it may contribute to a polarization of the Swiss electorate.

\section{Literature Review}

\subsection{Right-wing Populism in Switzerland}

The Swiss political system provides ideal opportunity structures for the emergence of populist communication. Indeed, rightwing populism has a strong tradition since the Swiss People's Party (SVP)'s upraise in the 1990s (Ernst, Engesser, \& Esser, 2017b). The SVP is the largest right-wing populist party in Western Europe and can count as a textbook example for populist parties. Under its former leader Christoph Blocher, the party has almost doubled its vote share; in 2003 it became Switzerland's largest party. Much of this success is attributed to the charismatic appeal of Blocher and to the radicalized rhetoric against immigration and EU integration that he introduced (Albertazzi, 2008; Skenderovic, 2007).

\subsection{Right-wing populist communication}

The communication of right-wing populist parties reflects their political ideas (Aalberg, Esser, Reinemann, Stromback, \& Vreese, 2016), which are influenced by the populist ideology on the one hand, and by a right-wing political orientation on the other hand. Populism as a thin-centered ideology describes a struggle over the structure of power in society; the pure and virtuous people feel deprived of 
their rights and values by the corrupt and self-serving elite (Albertazzi \& McDonnell, 2008) and want their will to be the ultimate say in politics (Mudde, 2004). On a communicative level, these ideas are expressed by praising the people, blaming the elite, and demanding more sovereignty for the people (Wirth et al., 2016). We refer to such expressions as populist statements. As populism is a thin-centered ideology (Kaltwasser, 2011; Mudde, 2004), it can be combined with other ideologies. Rightwing populism combines populism with nativism (Mudde, 2007). Nativism is the idea that a nation state should only be inhabited by locals and that people or ideas from outside present a threat to the state (Mudde, 2007, 2010). On a communicative level, nativism is reflected by statements that blame or discredit immigrants and exclude them from the people (Wirth et al., 2016). We refer to such expressions as antiimmigrant statements.

Right-wing populist communication can thus be understood as a combination of populist statements and anti-immigrant statements. The pure people are vertically distinguished from a corrupt elite, and horizontally distinguished from others who threaten their values and wellbeing. As right-wing populism combines an anti-elitist and an exclusionist perspective, it can also be referred to as complete populism (Jagers \& Walgrave, 2007; Reinemann, Aalberg, Esser, Strömbäck, \& de Vreese, 2016). This communicative repertoire can be enriched by populist communication styles.

Several scholars have measured manifestations of (right-wing) populist communication in traditional or new media (Akkerman, 2011; Cranmer, 2011; Engesser, Ernst, Esser, \& Büchel, 2017; Hameleers, Bos, \& de Vreese, 2017; Jagers \& Walgrave, 2007; Rooduijn, 2013). The focus, thereby, has mostly been on identifying populist statements and anti-immigrant statements in order to classify actors as more or less (right-wing) populist. Less attention has been devoted to the identification of populist style elements (see Bos \& Brants, 2014; Bracciale \& Martella, 2017 for exceptions). Although commu- nication styles such as emotionalization, dramatization, absolutism and colloquial language are often associated with populism (Albertazzi \& McDonnell, 2008; Betz, 1993; Canovan, 1999; Hawkins, 2009; Mazzoleni et al., 2003; Taggart, 2000), they are not direct expressions of the populist ideology and may have other causes, for example media logic. Their use does thus not classify actors as more or less populist. Nevertheless, a recent study by Wettstein et al. (2018) demonstrates that populist style elements are most likely to occur in newspaper articles when populist actors are a speaker. We therefore consider such style elements to be an element of rightwing populist communication and refer to them as populist styles (see Table 1). It is the purpose of this study to investigate if the combination of substantial right-wing populist statements (populist statements or anti-immigrant statements) with populist styles increases the persuasiveness of the former.

In Switzerland, especially the SVP is known to make use of populist communication, as empirical studies show. A recent study by Bernhard (2017) has analysed the use of populist statements by Swiss political parties in their newspapers. The results suggest that the SVP, together with the more regionally focused parties Ticino League (Lega) and Geneva Citizens Movement (MCG), make more populist statements than established parties (the Social Democrats, Liberals, Christian Democrats and Greens). Similarly, Ernst, Engesser, and Esser (2017a) found that the SVP makes more populist statements on Facebook and Twitter than the established parties (see also Ernst, Engesser, Büchel, Blassnig, \& Esser, 2017). These finding are consistent with results of an earlier study by Cranmer (2011), who found that in a media context, the SVP employed more populist statements and anti-immigrant statements than any other party in Switzerland. Of the nation-wide relevant parties in Switzerland, the SVP is thus the one that is most inclined to use right-wing populist communication. 
Table 1: Populist Key Messages and Populist Styles

\begin{tabular}{l|l}
\hline Populist Key Messages \\
\hline Anti-Elitism & $\begin{array}{l}\text { The elite in general or specific elites are des- } \\
\text { cribed with negative attributes (e. g., corrupt, } \\
\text { incompetent), as a threat or burden to the people, } \\
\text { as responsible for problems, as not belonging to/ } \\
\text { caring for the people. }\end{array}$ \\
\hline People Centrism & $\begin{array}{l}\text { The people are described with positive attributes } \\
\text { (e. g., competent, virtuous), as responsible for } \\
\text { a good development, as monolithic. The speaker } \\
\text { describes himself as part of the people/caring } \\
\text { for the people. }\end{array}$ \\
\hline Restoring & $\begin{array}{l}\text { It is argued in favor of more power to the people } \\
\text { or less power to the elites. }\end{array}$ \\
\hline Povereignty & Populist Styles \\
\hline Emotionalization & $\begin{array}{l}\text { Use of emotional language, references to } \\
\text { feelings }\end{array}$ \\
\hline Dramatization & $\begin{array}{l}\text { Using exaggerations, war rhetoric, describing the } \\
\text { situation as an emergency, declaring a scandal }\end{array}$ \\
\hline Absolutism & $\begin{array}{l}\text { Presenting something as the only conceivable } \\
\text { option }\end{array}$ \\
\hline Colloquial & $\begin{array}{l}\text { Use of vulgar or slang language, sarcasm, } \\
\text { nicknames }\end{array}$ \\
\hline Language
\end{tabular}

\subsection{Effects of right-wing populist content and style}

Several studies demonstrate that antiimmigrant statements and populist statements increase negative attitudes toward immigrants (Arendt, Marquart, \& Matthes, 2015; Matthes \& Schmuck, 2017; Schemer, 2012; Schmuck \& Matthes, 2017; Sheets, Bos, \& Boomgaarden, 2015). Much less is known about the effects of populist styles. However, two studies suggest that the persuasiveness of populist and antiimmigrant statements increases when they are combined with an emotionalized style (Hameleers, Bos, \& de Vreese, 2017a; Matthes \& Marquart, 2013). More generally, research on the formal presentation of news has shown that although style elements such as emotionalization and dramatization negatively influence the perceived quality of news (Kleemans, Vettehen, Beentjes, \& Eisinga, 2017), they positively affect arousal and attention (Grabe, Zhou, Lang, \& Bolls, 2000), and may also increase memory for some news stories (Grabe, Lang, \& Zhao, 2003). The use of populist style elements may thus increase the attention to anti-immigrant and populist statements in a news item as well as the perceived relevance of the news. We can therefore assume that the exposure to anti-immigrant and populist statements in news coverage on the issue of migration increases negative attitudes toward immigrants, and that this effect will be even larger when such statements are combined with populist style.

, Hla: The more often individuals are exposed to right-wing populist content (i. e., anti-immigrant and/or populist statements) in their media diets, the more negative will their attitudes toward immigrants become.

, H2a: The more often individuals are exposed to a combination of populist and anti-immigrant statements with populist style in their media diets, the more negative will their attitudes toward immigrants become.

The operationalization of negative attitudes toward immigrants varies considerably between and within studies. While some studies aim to depict what people think or feel about immigrants (e.g., Wirz et al., 2018), others also include support for immigration policies (e.g., Matthes \& Schmuck, 2017). In the Swiss context, where people can vote for immigration policies in referenda, it is very useful to distinguish between attitudes toward immigrants (consisting of cognitions and emotions toward immigrants, see Schemer, 2009), and support for immigration policies. As the extant literature did not fully distinguish between the two concepts so far, we can assume that the assumptions we made for anti-immigrant attitudes are also valid for the support of anti-immigrant policies.

, H1b: The more often individuals are exposed to right-wing populist content (i.e., anti-immigrant and/or populist statements) in their media diets, the stronger will their support for anti-immigrant policies become.

, H2b: The more often individuals are exposed to a combination of populist and anti-immigrant statements with 
populist style in their media diets, the stronger will their support for anti-immigrant policies become.

Some studies also demonstrate effects of right-wing populist communication on voting intentions for right-wing populist parties (Boomgaarden \& Vliegenthart, 2007; Hameleers, Bos, \& de Vreese, 2018; Sheets et al., 2016). These authors argue that anti-immigrant statements highlight the salience of immigration as a problem and lead to more support for parties that are perceived as providing solutions for this problem. Further, populist statements may increase political discontent and lead to more support for parties that are perceived as an alternative to the political establishment. We can thus assume that the exposure to right-wing populist content in the media does increase the support for right-wing populist parties in general, and in the Swiss context for the SVP in particular. Although the previous literature makes no assumption about the effects of populist style on voting intentions, we assume that the underlying process is the same as described for effects on anti-immigrant attitudes; the use of populist style elements in combination with anti-immigrant or populist statements will increase the relevance of the message, which leads to a higher salience of the issue and thus may increase the preference for a party that promises a solution. Therefore, we postulate that a combination of populist content with populist style will increase the vote probability for the SVP.

, H1c: The more often individuals are exposed to right-wing populist content (i. e., anti-immigrant and/or populist statements) in their media diets, the higher will their vote probability for the SVP become.

, H2c: The more often individuals are exposed to a combination of populist and anti-immigrant statements with populist style in their media diets, the higher will their vote probability for the SVP become.
Most studies on the effects of right-wing populist communication did not find effects across the board, but rather for specific voter segments. It seems that individuals with lower education (e.g. Matthes \& Marquart, 2013; Matthes \& Schmuck, 2017), lower issue-specific knowledge (Schemer, 2012), lower identification with those who are blamed (Hameleers et al., 2017b), higher identification with populist actors (Hameleers \& Schmuck, 2017), and higher political cynicism (Bos et al., 2013) are more susceptible to right-wing populist appeals. Most of these characteristics seem to reflect individuals' support of populist ideas. A study by Müller et al. (2017) has shown that pervious levels of support for the populist ideology determine individuals' responses to populist media content: individuals who support the populist ideology develop higher levels of support in response to populist statements in the news, while individuals who oppose the populist ideology develop lower levels of support in response to populist statements. Taken together, previous research seems to suggest that populist communication is more persuasive for individuals with an affinity to populism, and that it may even have reversed effects for individuals with low populist attitudes. We therefore postulate that the effects that we assumed in $\mathrm{H} 1$ and $\mathrm{H} 2$ will depend on individuals' populist attitudes.

\section{, H3: Persuasive effects of anti-immi-} grant statements, populist statements, and populist styles can only be expected for individuals with strong populist attitudes, while no persuasive (or even reversed) effects can be expected for individuals with low populist attitudes.

\section{Methods}

To test our hypotheses, we combined data from a content analysis and a two-wave panel-survey in a linkage-analysis (de Vreese et al., 2017; Scharkow \& Bachl, 2017). Based on the self-reported media use of the survey participants, we assigned individual scores of media content vari- 
ables, reflecting the content participants were most likely exposed to. This method allows us to investigate the effects of media exposure on changes in attitudes toward immigrants, support of anti-immigration policies, and vote probability for the SVP.

In order to detect media effects, it is important that the media selection for the content analysis reflects the media repertoires of the survey participants as good as possible. Therefore, we decided to focus our analysis on the metropolitan region of Zurich, consisting of the city of Zurich and the encompassing canton of Zurich. This focus allows us to include news outlets of national as well as regional scope. Further, the sample of survey participants still represents a diverse population, living in urban as well as rural areas and with diverse political views. Although the sample may not be fully representative of Switzerland, the results of recent referenda suggest the divide between urban and rural areas becomes more prominent, while regional differences have decreased ${ }^{2}$.

\subsection{Content Analysis}

The content analysis includes a wide selection of news media with a high share in the region of Zurich. We included the print editions of the Neue Zürcher Zeitung and Tages-Anzeiger (quality media), Blick and 20 Minuten (tabloid media), Winterthurer Zeitung and Zürcher Oberländer (regional news), Weltwoche and WOZ (weeklies). As there is usually a very high consonance of print and online edition of newspapers (Ghersetti, 2014), we considered the print versions also as proxies for the online content of those news outlets. Further, we included the two most viewed TV news shows in Switzerland, the Tagesschau and 10 vor 10 (both SRF 1 ).

We analyzed all those news outlets during a period of 59 days in February and March 2015 to include the last 30 days of news coverage before the second survey for each participant. Using a list of 20 keywords related to migration, we retrieved

2 As suggested by a data analysis at the EPFL Lausanne: https://actu.epfl.ch/news/swisspolitics-is-increasingly-dominated-by-anurb/ (last visited on June 6, 2018).
2487 articles, 1894 of which referred to migration politics. From these texts, a sample of 965 was drawn for detailed analysis. For TV shows, we used artificial weeks and manual scanning to identify 34 news stories on migration. All variables were coded on statement levels by a team of 39 trained coders and then aggregated on the news item. Reliability was assessed between coders and between each coder and a gold standard provided by the project leaders for a subsample of the news items in the analysis (Mean agreement: 93.2\%; B\&P Kappa $=0.90)$.

\subsubsection{Measures}

For the present study, we measured three relevant variables in the media content. First, we measured anti-immigrant statements. For each statement about immigrants, coders decided if the valence was positive or negative, or if promoted policies were in favor or in opposition of restrictions on immigration. We aggregated this measure on the news item creating a bias variable which indicates if the news item in total is more favorable or unfavorable toward immigrants. Positive values on this variable indicate an anti-immigrant bias. Second, we assessed the dominance of populist statements over anti-populist statements in a similar procedure. Statements were coded as populist when they reflect one of the populist key messages displayed in Table 1, and as anti-populist, when they reflect the opposite of these ideas (i. e., an elitist or pluralist view). Positive values on the bias variable indicate that the news item contains more populist than anti-populist statements. And third, we measured the number of populist style elements and aggregated them as a sum for each news item. We considered emotionalization, dramatization, absolutism and the use of colloquial language as populist communication styles (compare Table 1). As this count variable is heavily skewed (most articles contain no or few style elements), it was transformed before the statistical analysis by calculating its natural logarithm.

In order to assess if the combination of substantial right-wing populist content 
with populist style elements increases the persuasiveness of populist communication, we computed two dummy variables from these measures: a first one indicating the co-occurrence of anti-immigrant statements and populist style in a news item, and a second one indicating the co-occurrence of populist statements and populist style. Both of these variables have the value 1 when a news item has a positive value on the bias variable and contains at least one style element, and the value 0 if these conditions are not met $^{3}$.

\subsection{Panel Survey}

The panel survey was conducted online in April 2014 and March 2015. Participants were recruited by a professional market research company from their online access panel using a quota procedure for age and gender. 2000 persons participated in the first panel wave. Due to the long time span between the two waves, about one third of the sample dropped out. Further, participants in the survey who indicated that they do neither read one of the newspapers (print or online edition) nor watch one of the TV news shows in the analysis had to be excluded for the purpose of this study $(\mathrm{n}=88)$. The final sample consisted of 1172 participants, 46 percent were female and the age ranged from 19 to 74 years with a mean of 52 years. Most participants had a medium (51 percent) or high (46 percent) education level, while the other participants had only mandatory education ( 2 percent) or did not indicate their education level ( 1 percent).

\subsubsection{Measures}

The panel survey measured the dependent and moderator variables of interest for this study, as well as the participants' me-

3 We prefer this dummy coding over an interaction term due to the nature of the bias variables: We are interested in the effects of populist and anti-immigrant statements combined with populist styles compared to such statements that are not combined with style elements, but we make no assumptions about the effects of anti-populist and pro-immigrant statements with style elements. dia diets. First, anti-immigrant attitudes were measured as a latent construct with six items representing negative cognitions (e.g., "foreigners are criminals") or negative emotions (i.e., "When I think of foreigners, I feel fear.") toward immigrants in a procedure adapted from Crites, Fabrigar, and Petty (1994). Second, the support for anti-immigration policies was measured as a latent construct with four items (e.g., "People from Switzerland should always be offered jobs before migrants."). Scalar measurement invariance over time was established for both latent constructs. Third, the vote probability for the Swiss People's Party was assessed with a single item (How likely would you vote for the SVP if elections were today?). All three dependent variables are significantly and positively correlated $(p<0.001)$; anti-immigrant attitudes and the support for anti-immigrant policies have a strong correlation $(\mathrm{r}=0.86)$, and both latent constructs are moderately correlated with vote probability for the SVP $(r=0.34$ and $\mathrm{r}=0.38)$. Populist attitudes, which served as a moderator in this study's analysis and represent the degree of support for the populist ideology, were measured with a scale by Schulz et al. (2018). This measure consists of 12 items (e.g., "MPs in Parliament very quickly lose touch with ordinary people."), that we combined in a mean index (Cronbach's Alpha $=0.88$ ) and split at the median in order to obtain a dichotomous moderator. All items were measured with 5-point Likert-type scales in both panel waves.

Participants' media use was measured in a three step procedure using the list frequency technique (Andersen, de Vreese, \& Albæk, 2016). First, participants indicated which channels (print, TV, online) they used to get political information. Then, for each selected channel, a list of news media outlets was presented, from which respondents could select the ones they used at least sometimes. In the last step, they were presented all selected outlets and asked about the frequency of use during a week (1 to 7 days). 
Table 2: Regression coefficients of the multi-group structural equation model

\begin{tabular}{|c|c|c|c|c|c|c|}
\hline \multirow[t]{2}{*}{ Populist Attitudes } & \multicolumn{2}{|c|}{ all } & \multicolumn{2}{|c|}{ low } & \multicolumn{2}{|c|}{ high } \\
\hline & $\beta$ & $p$ & $\beta$ & $p$ & $\beta$ & $p$ \\
\hline \multicolumn{7}{|c|}{ Latent variable: Anti-immigrant attitudes t2 } \\
\hline Anti-immigrant attitudes t1 & 0.805 & .000 & 0.777 & .000 & 0.774 & .000 \\
\hline $\begin{array}{l}\text { Anti-immigration statements } \\
\text { (bias) }\end{array}$ & -0.027 & .519 & -0.046 & .403 & 0.001 & .998 \\
\hline Populist statements (bias) & 0.049 & .353 & $0.135^{*}$ & $.051^{*}$ & $-0.030^{*}$ & $.753^{*}$ \\
\hline Populist style & -0.055 & .070 & -0.029 & 0.475 & -0.071 & .169 \\
\hline $\begin{array}{l}\text { Anti-immigrant bias } \\
\text { with populist style }\end{array}$ & -0.060 & .334 & -0.131 & .100 & 0.002 & .983 \\
\hline $\begin{array}{l}\text { Populist bias with populist } \\
\text { style }\end{array}$ & 0.084 & .029 & $0.040^{*}$ & $.428^{*}$ & $0.132^{*}$ & $.035^{*}$ \\
\hline \multicolumn{7}{|c|}{ Latent variable: Support for anti-immigrant policies t2 } \\
\hline $\begin{array}{l}\text { Support for anti-immigrant } \\
\text { policies t1 }\end{array}$ & 0.969 & .000 & 0.959 & .000 & 0.957 & .000 \\
\hline $\begin{array}{l}\text { Anti-immigration statements } \\
\text { (bias) }\end{array}$ & 0.022 & .598 & 0.018 & .790 & 0.035 & .619 \\
\hline Populist statements (bias) & -0.072 & .200 & -0.031 & .713 & -0.155 & .085 \\
\hline Populist style & 0.006 & .845 & -0.012 & .785 & 0.041 & .408 \\
\hline $\begin{array}{l}\text { Anti-immigrant bias with } \\
\text { populist style }\end{array}$ & 0.128 & .037 & 0.144 & .119 & 0.150 & .154 \\
\hline $\begin{array}{l}\text { Populist bias with populist } \\
\text { style }\end{array}$ & -0.097 & .005 & $-0.159^{*}$ & $.004^{*}$ & $-0.057^{*}$ & $.309^{*}$ \\
\hline \multicolumn{7}{|c|}{ Latent variable: Support for anti-immigrant policies t2 } \\
\hline Vote probability SVP t1 & 0.844 & .000 & 0.848 & .000 & 0.802 & .000 \\
\hline $\begin{array}{l}\text { Anti-immigration statements } \\
\text { (bias) }\end{array}$ & 0.021 & .525 & 0.002 & .936 & 0.043 & .395 \\
\hline Populist statements (bias) & 0.037 & .363 & 0.007 & .899 & 0.079 & .243 \\
\hline Populist style & -0.013 & .566 & -0.009 & .781 & -0.013 & .711 \\
\hline $\begin{array}{l}\text { Anti-immigrant bias with } \\
\text { populist style }\end{array}$ & 0.004 & .926 & 0.071 & .307 & -0.069 & .387 \\
\hline $\begin{array}{l}\text { Populist bias with populist } \\
\text { style }\end{array}$ & -0.050 & .050 & -0.074 & .030 & -0.033 & .430 \\
\hline
\end{tabular}

Note. Significant effects are highlighted with gray areas, effects that differ significantly between groups are marked with an asterisk.

\subsection{Linkage Procedure}

Based on these self-reported media diets, participants were allocated the media content they were most likely exposed to. For each variable in the content analysis, we created an additive score for all articles within one medium per day. Participants were then allocated a mean score of all daily values for each media outlet they indicated to use. Outlets that were used 1-3 days a week were weighted 0.5 and outlets used 4-7 days a week were weighted 1 for the calculation of the total daily score for each participant. As a result of this procedure, each participant was allocated an individual score of the overall anti-immigrant bias, populist bias, number of style elements, and number of articles with a combination of populist or anti-immigrant statements with populist style. Each of these scores represents the individual average exposure per day.

\section{Results}

First, we report descriptive results for the media content that individuals were exposed to. The average news consumer was exposed to a very balanced portrayal of immigrants, with a bias score close to zero $(M=-0.09, S D=0.54)$. Populist statements were slightly dominant over anti-populist statements $(M=0.16, S D=0.54)$; and close 
Figure 1: Theoretical model depicting the assumed media effects

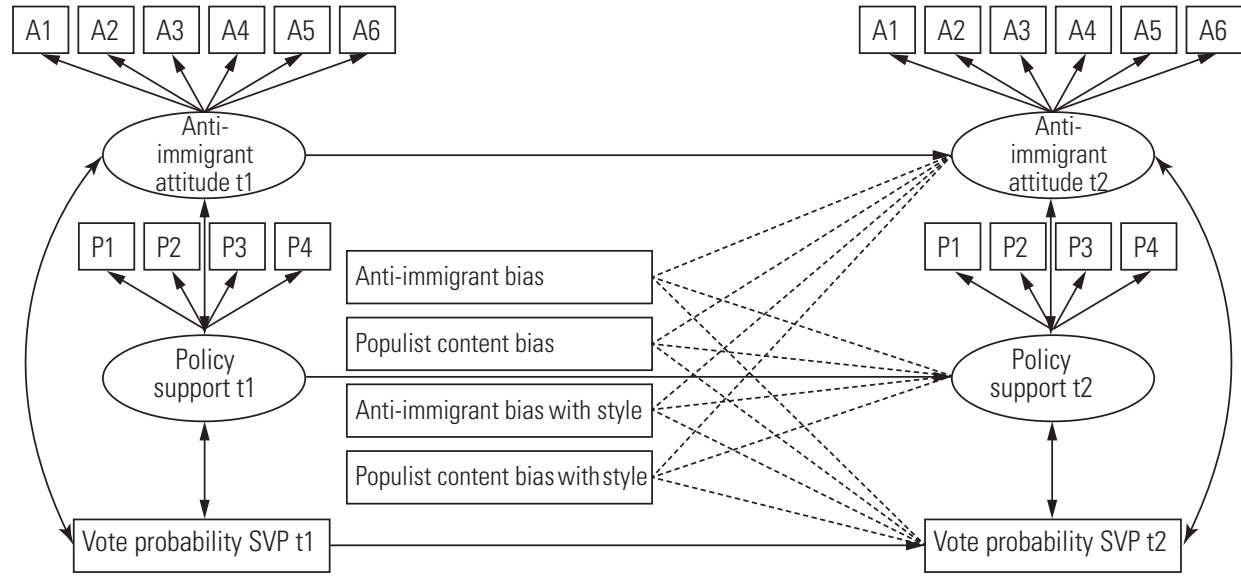

Note: Correlations between anti-immigrant attitudes, support for anti-immigration policies and SVP vote probability across time are not displayed for a better readability.

to five style elements were present in a daily media diet $(M=4.13, S D=2.29)$. Further, the average news consumer was exposed to a combination of anti-immigrant statements and style elements nearly every second day $(M=0.48, S D=0.22)$; and similarly often to a combination of populist statements and style elements $(M=0.57$, $S D=0.31$ )

In order to test our hypotheses, we first estimated a Structural Equation Model (SEM) for all participants with the $\mathrm{R}$ package lavaan (Rosseel, 2011). The theoretical model is displayed in Figure 1. It assumes that anti-immigrant attitudes, the support for anti-immigration policies and the vote probability for the SVP at the time of the second panel wave are predicted by an auto-regressive effect (i.e., the measure of the same construct at the time of the first panel wave) and by the media content individuals were exposed to in the 30 days prior to the second panel wave. Further, it assumes that anti-immigrant attitudes, the support for anti-immigrant policies, and the vote probability for the SVP are correlated, both within and across time points. The model has an acceptable to good fit to the data $\left(\mathrm{Chi}^{2}=801.36, \mathrm{df}=284\right.$, CFI: 0.96, TLI: 0.95, RMSEA: 0.04, SRMR: 0.06 ), according to the limits defined by Hu \& Bentler (1999).
As we assumed differential effects for individuals with lower and higher populist attitudes, we also estimated the model as a Multi-Group SEM. Also this model has an acceptable to good fit to the data $\left(C h i^{2}=1086.64, d f=568\right.$, CFI: 0.95, TLI: 0.94, RMSEA: 0.04, SRMR: 0.05). In order to determine if the differences between the two groups are statistically significant, we used a manifest modelling approach, that is a path model in which we included an interaction term for each media content variable with the measure of populist attitudes. The regression coefficients for the overall and multi-group estimation are both displayed in Table 2. Effects that can be considered to be statistically different between groups (as there was a significant interaction in the path model) are marked with an asterisk.

In a first step, we test $\mathrm{H} 1$ and $\mathrm{H} 2$ for the overall sample. Hypothesis 1 predicted that the exposure to right-wing populist content would lead to a) more negative attitudes toward immigrants, b) higher support of anti-immigration policies, and c) increase the vote probability of the SVP. There is no evidence for any of these effects. H1 a-c thus have to be rejected. Hypothesis 2 predicted that populist style elements would increase the persuasiveness of right-wing populist content. We found mixed evidence 
Figure 2: Overview of results

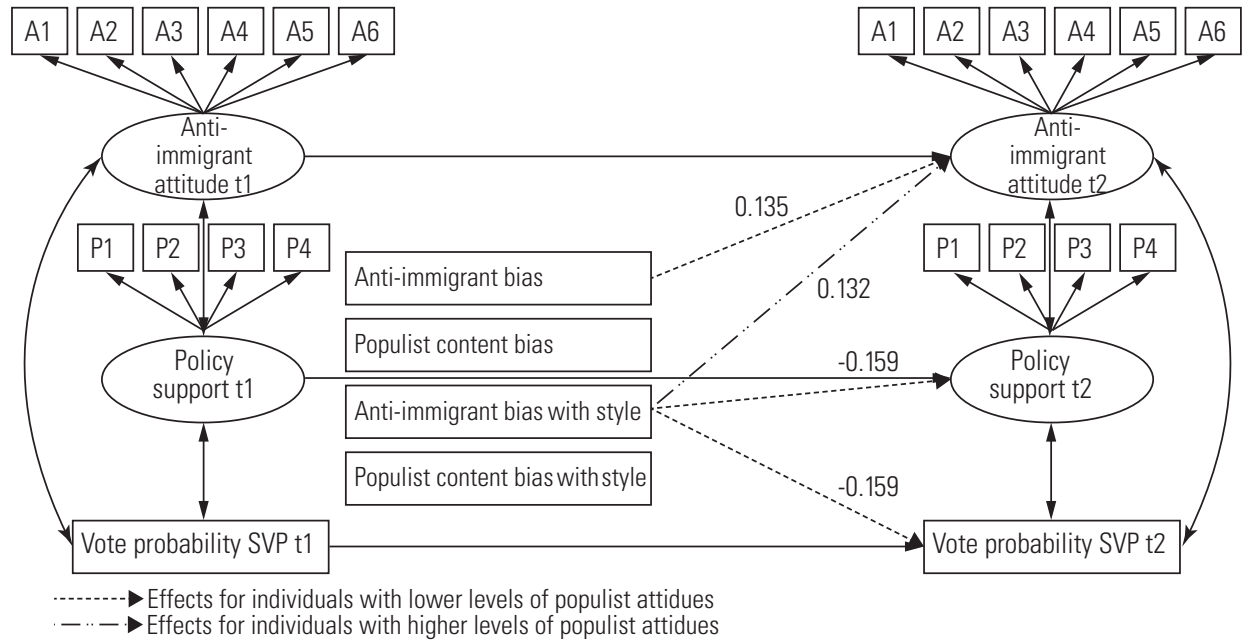

Note: Correlations between anti-immigrant attitudes, support for anti-immigration policies and SVP vote probability across time are not displayed for a better readability.

for this assumption. Combining populist statements with populist styles increased negative attitudes toward immigrants, but decreased the support for anti-immigrant policies and the vote probability for the SVP. Anti-immigrant statements combined with populist style increased the support for anti-immigrant policies but had no effect on anti-immigrant attitudes and vote probability for the SVP.

Hypothesis 3 predicted that persuasive effects of right-wing populist communication would only occur for individuals with high levels of populist attitudes. Although there are some significant effects for the overall sample, a look at the multi-group model suggests that there are indeed differential effects depending on the level of populist attitudes. First of all, the negative effects of populist statements combined with populist style can only be found for individuals with low populist attitudes. For this group, the combination of populist statements with style elements led to less support for anti-immigrant policies and a lower vote probability for the SVP. This is consistent with the expectations in H3. Second, the positive effect of populist statements with style elements can only be found for individuals with high populist attitudes. For this group, the combination of populist statements with populist style led to more negative attitudes toward immigrants. This is also consistent with H3. The mixed effects that we found for $\mathrm{H} 2$ can thus largely be explained by participants' populist attitudes.

Surprisingly, the overall effect of antiimmigrant statements combined with populist style is not significant in any of the two groups by themselves. On the other hand, there is an additional effect of populist statements (without style) for individuals with low populist attitudes. The more populist statements individuals in this group received in their media diet, the more negative did their attitudes toward immigrants become. This finding supports H1a, but contradicts H3, as we did not expect persuasive effects for individuals with low populist attitudes.

All in all, we can conclude that mainly the combination of anti-immigrant statements with populist style elements had an influence on Swiss citizens' attitudes. As expected, this influence was positive for individuals who support the populist ideology, and negative for those who oppose it. Further, also populist statements had an influence on attitudes toward immigrants, however unexpectedly only for individuals 
with low levels of populist attitudes. All significant effects are displayed in Figure 2.

\section{Discussion}

Although the Swiss People's Party has become the largest party in Switzerland, there has so far been no systematic analysis of how right-wing populist communication influences Swiss citizens' preferences for the SVP and its policies. One important feature of populist communication is the depiction of the situation as a crisis (Moffitt, 2015). It was therefore the aim of this study to investigate how the exposure to populist crisis rhetoric in the news influences citizens' attitudes toward immigrants, anti-immigration policies, and the probability to vote for the SVP. The results of this study suggest that the combination of substantial populist content with populist style elements, such as emotionalization or dramatization, does indeed have an impact. In line with previous research, for example by Müller et al. (2017), we found that individuals who support the populist ideology are persuaded by the combination of anti-immigrant statements with populist style, while individuals who oppose the populist ideology show reversed tendencies.

Interestingly, we only found effects for the combination of anti-immigrant content with populist style, but not for populist content with populist style. It might be that this is related to the concepts we investigated - it seems reasonable that antiimmigrant statements more than populist statements influence what people think about immigrants and immigration policies. As immigration is also the main issue of the SVP (Dalmus, Hänggli, \& Bernhard, 2016), it may be that reasons to vote or not vote for this party are dominated by considerations about the party's position on this issue. Further, one has to keep in mind that the effects reflect changes in attitudes or vote probability during one year. In this context, it is noteworthy that the combination of anti-immigrant statements with populist style affected attitudes toward immigrants, but not toward immigration pol- icies or the vote probability for the SVP for individuals with higher populist attitudes, while it was just the other way around for individuals with lower levels of populist attitudes. This might indicate that the proclamation of an immigration crisis is perceived as an over-dramatization by individuals who are not inclined toward the populist ideology; it has no effect on their attitudes toward immigrants and leads to a rejection of the SVP and its policies. For individuals who support the populist ideology on the other hand, the proclamation of such a crisis is persuasive, however they might support (or not support) the SVP and its policies for other reasons.

A surprising result of this study is that the exposure to populist statements led to more negative attitudes toward immigrants for individuals with low populist attitudes. The depiction of a conflict between the people and the elite in the context of immigration might have increased the perception of immigration as a problem for this group, even or probably because they usually do not feel betrayed by the political elite. It might be that as this group rejects a tough anti-immigrant rhetoric, other and more subtle arguments against immigration are more persuasive for them. The effect may also have methodological reasons: Individuals with low populist attitudes had significantly less negative attitudes toward immigrants than individuals with high populist attitudes at the first panel wave; considering what is known as regression to the mean (Barnett, van der Pols, \& Dobson, 2005), it might be that individuals in this group just reported less extreme attitudes at the time of the second panel wave (while however individuals with high populist attitudes stayed as extreme as they were).

The present research of course has its limitations. The linkage analysis is based on the assumption that individuals were exposed to all articles on the issue of migration in the media outlets that they use. This is a very idealistic assumption. The measurement error is further increased by the self-report of media use, and by the fact that we only analyzed a random sample of the media content. This might have 
led to an underestimation of media effects (Scharkow \& Bachl, 2017). It is therefore noteworthy to mention that we did find some media effects, despite the potential inaccuracy in the assignment of media content. The media effects we found are only small, which is however not surprising as we investigate attitude change in a panel design. Future research could address the problem of measurement error by using tracking data for media use, or by considering the placement of news items (e.g., front page versus other pages) in order to estimate the probability that survey participants were exposed to a particular news story.

Another limitation is the focus on some selected news sources, which of course do not reflect the complete media repertoire of the population. We analyzed TV news and print newspapers, and considered the latter also as proxies for the online outlets. As digital-born news media still play a minor role in Switzerland (Newman, Fletcher, Levy, \& Nielsen, 2016), this selection reflects the main mass media news sources of the Swiss population. However, especially on social media, individuals are not only exposed to news from established Swiss media, but also to messages from foreign media, alternative news sources, and messages from peers. As this exposure is very individual, it will be a big challenge for future research to better acknowledge such sources.

The present study focused on the effects of right-wing populist communication in the metropolitan region of $\mathrm{Zu}$ rich and its impact on the support of the SVP and its policies. Although the SVP is characterized as a textbook example for a right-wing populist party, right-wing populist communication in the news is not limited to this party, and may also affect the vote probability for other Swiss parties. It would thus be desirable for future research to enhance the scope of analysis. Further, in order to enhance the generalizability of our findings with regard to populist parties, similar analyses could also be conducted in the area of Geneva with the Geneva Citizens Movement (MCG), or in Ticino with the Ticino League (Lega).
Despite its limitations, the present study provides some valuable contributions. First, with a more general scope, this research has shown that populist crisis rhetoric, that is, the combination of substantial (right-wing) populist content with a populist style, is persuasive for some voter segments, but does backfire for others. The combination of populist messages with an arousing style is thus not such a powerful persuasion tool as some might have hoped or feared. However, the results of our analysis suggest that also voters who rather oppose the populist ideology may be persuaded by populist communication, although they react to different cues than individuals who support the populist ideology.

Second, with a more specific focus on Switzerland, the study at hand is the first analysis of the effects of right-wing populist communication in the news on Swiss citizens' attitudes. It shows that dramatization in the context of anti-immigrant rhetoric had a negative impact on vote probability for the SVP and on support of anti-immigration policies for voters with lower levels of populist attitudes. This is noteworthy, as the first panel wave of this study took place in 2015, just after the Swiss electorate accepted the «Masseneinwanderungsinitiative», a referendum launched by the SVP which demanded the limitation of immigration to Switzerland through contingents, while the second panel wave took place a year later. At the moment of writing, the Masseneinwanderunginitiative was the last success of the SVP on the immigration issue. In 2016, the Swiss electorate voted against the «Durchsetzungsinitivative», which wanted to establish stricter rules for the deportation of foreign criminals. The results of our study, which depict the change in attitudes toward immigrants and immigration policies between 2015 and 2016, might provide some explanation for the diverging outcomes of these two referenda. 


\section{References}

Aalberg, T., Esser, F., Reinemann, C., Stromback, J., \& de Vreese, C. H. (2016). Populist political communication in Europe. New York: Routledge.

Albertazzi, D. (2008). Switzerland: Yet another populist paradise. In Twenty-First Century Populism (pp. 100-118). London, UK: Palgrave Macmillan. doi:10.1057/9780230592100_7

Albertazzi, D., \& McDonnell, D. (2008). Introduction: The sceptre and the spectre. In D. Albertazzi \& D. McDonnell (Eds.), Twenty-first century populism: The spectre of Western European democracy (pp. 1-11). Basingstoke and New York: Palgrave Macmillan.

Andersen, K., de Vreese, C. H., \& Albæk, E. (2016). Measuring media diet in a highchoice environment - Testing the list-frequency technique. Communication Methods and Measures, 10(2-3), 81-98. doi:10.1080/19312458.2016.1150973

Arendt, F., Marquart, F., \& Matthes, J. (2015). Effects of right-wing populist political advertising on implicit and explicit stereotypes. Journal of Media Psychology, 27(4), 178-189. doi:10.1027/1864-1105/a000139

Barnett, A. G., van der Pols, J. C., \& Dobson, A. J. (2005). Regression to the mean: What it is and how to deal with it. International Journal of Epidemiology, 34(1), 215-220. doi:10.1093/ije/dyh299

Bernhard, L. (2017). Three faces of populism in current Switzerland: Comparing the populist communication of the Swiss People's Party, the Ticino League, and the Geneva Citizens' Movement. Swiss Political Science Review, 23(4), 509-525. doi:10.1111/spsr.12279

Betz, H.-G. (1993). The new politics of resentment: Radical right-wing populist parties in Western Europe. Comparative Politics, 25(4), 413-427.

Boomgaarden, H. G., \& Vliegenthart, R. (2007). Explaining the rise of anti-immigrant parties: The role of news media content. Electoral Studies, 26(2), 404-417. doi:10.1016/j.electstud.2006.10.018

Bos, L., \& Brants, K. (2014). Populist rhetoric in politics and media: A longitudinal study of the Netherlands. European Jour- nal of Communication, 29(6), 703-719. doi:10.1177/0267323114545709

Bos, L., van der Brug, W., \& de Vreese, C. H. (2013). An experimental test of the impact of style and rhetoric on the perception of right-wing populist and mainstream party leaders. Acta Politica, 48(2), 192-208. doi:10.1057/ap.2012.27

Bracciale, R., \& Martella, A. (2017). Define the populist political communication style: the case of Italian political leaders on Twitter. Information, Communication \& Society, 20(9), 1310-1329. doi:10.1080/1369118X.2017.1328522

Canovan, M. (1999). Trust the people! Populism and the two faces of democracy. Political Studies, 47(1), 2-16. doi:10.1111/1467-9248.00184

Cranmer, M. (2011). Populist communication and publicity: An empirical study of contextual differences in Switzerland. Swiss Political Science Review, 17(3), 286-307. doi:10.1111/j.1662-6370.2011.02019.x

Crites, S. L., Fabrigar, L. R., \& Petty, R. E. (1994). Measuring the affective and cognitive properties of attitudes: Conceptual and methodological issues. Personality and Social Psychology Bulletin, 20(6), 619-634. doi:10.1177/0146167294206001

Dalmus, C., Hänggli, R., \& Bernhard, L. (2016). Issue competition between parties across communication channels: An empirical analysis of the 2011 Swiss federal elections. NCCR Challenges to Democracy in the $21^{\text {st }}$ Century (Working Paper No. 93).

de Vreese, C. H., Boukes, M., Schuck, A., Vliegenthart, R., Bos, L., \& Lelkes, Y. (2017). Linking survey and media content data: Opportunities, considerations, and pitfalls. Communication Methods and Measures, 11(4), 221-244. doi:10.1080/19312458.2017.1380175

Ernst, N., Engesser, S., Büchel, F., Blassnig, S., \& Esser, F. (2017). Extreme parties and populism: An analysis of Facebook and Twitter across six countries. Information, Communication \& Society, 20(9), 1347-1364. doi:10.1080/1369118X.2017.1329333

Ernst, N., Engesser, S., \& Esser, F. (2017a). Bipolar populism? The use of anti-elitism and people-centrism by Swiss parties on social media. Swiss Political Science Re- 
view, 23(3), 253-261.

doi:10.1111/spsr. 12264

Ernst, N., Engesser, S., \& Esser, F. (2017b). Switzerland: Favorable conditions for growing populism. In T. Aalberg, F. Esser, C. Reinemann, J. Stromback, \& C. De Vreese (eds.), Populist Political Communication in Europe (pp. 151-164). New York: Routledge.

Ghersetti, M. (2014). Still the same?: Comparing news content in online and print media. Journalism Practice, 8(4), 373-389. doi:10.1080/17512786.2013.813201

Grabe, M. E., Lang, A., \& Zhao, X. (2003). News content and form: Implications for memory and audience evaluations. Communication Research, 30(4), 387-413. doi:10.1177/0093650203253368

Grabe, M. E., Zhou, S., Lang, A., \& Bolls, P. D. (2000). Packaging television news: The effects of tabloid on information processing and evaluative responses. Journal of Broadcasting \& Electronic Media, 44(4), 581-598.

doi:10.1207/s15506878jobem4404_4

Hameleers, M., Bos, L., \& de Vreese, C. H. (2017a). Shoot the messenger? The media's role in framing populist attributions of blame. Journalism, 1464884917698170. doi:10.1177/1464884917698170

Hameleers, M., Bos, L., \& de Vreese, C. H. (2017b). "They did it”: The effects of emotionalized blame attribution in populist communication. Communication Research, 44(6), 870-900. doi:10.1177/0093650216644026

Hameleers, M., Bos, L., \& de Vreese, C. H. (2018). Selective exposure to populist communication: How attitudinal congruence drives the effects of populist attributions of blame. Journal of Communication, 68(1), 51-74. doi:10.1093/joc/jqx001

Hameleers, M., \& Schmuck, D. (2017). It's us against them: a comparative experiment on the effects of populist messages communicated via social media. Information, Communication \& Society, 20(9), 14251444. doi:10.1080/1369118X.2017.1328523

Hawkins, K. A. (2009). Is Chávez populist? Measuring populist discourse in comparative perspective. Comparative Political Studies, 42(8), 1040-1067. doi:10.1177/0010414009331721
Jagers, J., \& Walgrave, S. (2007). Populism as political communication style: An empirical study of political parties' discourse in Belgium. European Journal of Political Research, 46(3), 319-345. doi:10.1111/j.1475-6765.2006.00690.x

Kaltwasser, C. R. (2011). The ambivalence of populism: Threat and corrective for democracy. Democratization, 19(2), 184-208. doi:10.1080/13510347.2011.572619

Kleemans, M., Vettehen, P. G. J. H., Beentjes, J. W. J., \& Eisinga, R. (2017). The influence of sensationalist features in television news stories on perceived news quality and perceived sensationalism of viewers in different age groups. Studies in Communication Sciences, 17(2), 183-194. doi:10.24434/j.scoms.2017.02.004

Matthes, J., \& Marquart, F. (2013). Werbung auf niedrigem Niveau? Publizistik, 58(3), 247-266. doi:10.1007/s11616-013-0182-0

Matthes, J., \& Schmuck, D. (2017). The effects of anti-immigrant right-wing populist ads on implicit and explicit attitudes: A moderated mediation model. Communication Research, 44(4), 556-581. doi:10.1177/0093650215577859

Mazzoleni, G., Stewart, J., \& Horsfield, B. (Eds.). (2003). The media and neo-populism: A Contemporary comparative analysis. Westport: Praeger.

Moffitt, B. (2015). How to perform crisis: A model for understanding the key role of crisis in contemporary populism. Government and Opposition, 50(2), 189-217. doi:10.1017/gov.2014.13

Mudde, C. (2004). The populist Zeitgeist. Government and Opposition, 39(4), 542-563. doi:10.1111/j.1477-7053.2004.00135.x

Mudde, C. (2007). Populist radical right parties in Europe. Cambridge: Cambridge University Press.

Mudde, C. (2010). The populist radical right: A pathological normalcy. West European Politics, 33(6), 1167-1186. doi:10.1080/01402382.2010.508901

Müller, P., Schemer, C., Wettstein, M., Schulz, A., Wirz, D. S., Engesser, S., \& Wirth, W. (2017). The polarizing impact of news coverage on populist attitudes in the public: Evidence from a panel study in four European democracies. Journal of Com- 
munication, 67(6), 968-992.

doi:10.1111/jcom.12337

Newman, N., Fletcher, R., Levy, D. A. L., \& Nielsen, R. K. (2016). Reuters Institute Digital News Report 2016. Oxford: Reuters Institute for the Study of Journalism.

Reinemann, C., Aalberg, T., Esser, F., Strömbäck, J., \& de Vreese, C. H. (2016). Populist political communication: Towards a model of its causes, forms, and effects. In T. Aalberg, F. Esser, C. Reinemann, J. Strömbäck, \& C. H. de Vreese (Eds.), Populist political communication in Europe (pp. 12-25). New York: Routledge.

Rosseel, Y. (2011). lavaan: An R package for structural equation modeling and more Version 0.4-9 (BETA). Ghent University.

Scharkow, M., \& Bachl, M. (2017). How measurement error in content analysis and self-reported media use leads to minimal media effect findings in linkage analyses: A simulation study. Political Communication, 34(3), 323-343.

doi:10.1080/10584609.2016.1235640

Schemer, C. (2009). Politische Kampagnen für Herz und Verstand. Affektive und kognitive Einflüsse der Massenmedien auf politische Einstellungen. Baden-Baden: Nomos.

Schemer, C. (2012). The influence of news media on stereotypic attitudes toward immigrants in a political campaign. Journal of Communication, 62(5), 739-757. doi:10.1111/j.1460-2466.2012.01672.x

Schmuck, D., \& Matthes, J. (2017). Effects of economic and symbolic threat appeals in right-wing populist advertising on anti-immigrant attitudes: The impact of textual and visual appeals. Political Communication, 34(4), 607-626. doi:10.1080/10584609.2017.1316807

Schulz, A., Müller, P., Schemer, C., Wirz, D. S., Wettstein, M., \&Wirth, W. (2018). Measuring populist attitudes on three dimensions. International Journal of
Public Opinion Research, 30(2), 316-326. doi:10.1093/ijpor/edw037

Sheets, P., Bos, L., \& Boomgaarden, H. G. (2016). Media cues and citizen support for right-wing populist parties. International Journal of Public Opinion Research, 28(3), 307-330. doi:10.1093/ijpor/edv014

Skenderovic, D. (2007). Immigration and the radical right in Switzerland: Ideology, discourse and opportunities. Patterns of Prejudice, 41(2), 155-176. doi:10.1080/00313220701265528x

Taggart, P. (2000). Populism. Buckingham: Open University Press.

Udris, L. (2012). Is the populist radical right (still) shaping the news? Media attention, issue ownership and party strategies in Switzerland. Working Paper.

Wettstein, M., Esser, F., Büchel, F., Schemer, C. Wirz, D. S., Schulz, A., ...Wirth, W. (2018). What drives populist styles? Analyzing immigration and labor market news in 11 countries. Journalism \& Mass Communication Quarterly. Advance online publication. doi:10.1177/1077699018805408

Wirth, W., Esser, F., Wettstein, M., Engesser, S., Wirz, D., Schulz, A., ... others. (2016). The appeal of populist ideas, strategies and styles: A theoretical model and research design for analyzing populist political communication. Retrieved from http:// www.nccr-democracy.uzh.ch/publications/workingpaper/pdf/wp_88.pdf

Wirz, D. S., Wettstein, M., Schulz, A., Müller, P. Schemer, C., Ernst, N., ...Wirth, W. (2018). The effects of right-wing populist communication on emotions and cognitions toward immigrants. The International Journal of Press/Politics, 23(4), 496-516. doi:10.1177/1940161218788956 
